\title{
Hubungan Gratitude dan Subjective Well-Being Odapus Wanita Dewasa Awal di Syamsi Dhuha Foundation Bandung
}

\author{
Nadia Felicia Mahardhika, Lilim Halimah \\ Universitas Islam Bandung, Jl. Tamansari No.1 Bandung 40116 \\ $e$-mail : nadiafeliciamahardhika@yahoo.com
}

\begin{abstract}
Systemic Lupus Erythematosus is a chronic illness, in which $90 \%$ of the sufferers are early adult women. They faced many difficulties which can cause depressions. People with lupus in Syamsi Dhuha Foundation show high positive affect and said that they satisfied with their lives. This research is a population research to 30 people with lupus in Syamsi Dhuha Foundation, using correlational technique. The goal is to examine the correlation between gratitude and subjective well-being of early adult women with lupus at Syamsi Dhuha Foundation. The instrument for gratitude is GRAT-R (Watkins, 2002) and for subjective wellbeing are SPANE (Diener, 2012), SWLS (Diener, 1987), and Domain Satisfaction Scales (Public Attitudes and Behaviours towards the Environment Omnibus Survey, 2007). The results are: 1) Strong positive correlation between gratitude and subjective well-being; 2) Twenty seven subjects who show high gratitude; and 3) Twenty one subjects report high subjective well-being.
\end{abstract}

Keywords: lupus, gratitude, Positive Psychology, subjective well-being, Syamsi Dhuha Foundation

\begin{abstract}
Abstrak
Systemic Lupus Erythematosus merupakan chronic illness yang 90\% penderitanya adalah wanita dewasa awal. Odapus mengalami banyak sekali keadaan yang sulit dalam berbagai aspek yang membuat odapus mengalami depresi. Namun, odapus di Syamsi Dhuha Foundation menunjukkan ekspresi afek positif dan puas dengan hidup mereka, sebab menganggap banyak pemberian Tuhan yang berharga. Penelitian ini merupakan penelitian populasi terhadap 30 orang odapus di Syamsi Dhuha Foundation, menggunakan teknik korelasional. Tujuannya untuk melihat keeratan hubungan di antara gratitude dan subjective well-being pada odapus wanita dewasa awal di Syamsi Dhuha Foundation. Alat ukur gratitude menggunakan GRAT$\mathrm{R}$ (Watkins, 2002), subjective well-being menggunakan SPANE (Diener, 2012), SWLS (Diener, 1987), dan Domain Satisfaction Scales (Public Attitudes and Behaviours towards the Environment Omnibus Survey, 2007). Hasil penelitian: (1) Hubungan positif yang signifikan kuat $(\mathrm{r}=0,875)$ antara gratitude dan subjective well-being. (2) Sebanyak 27 odapus melaporkan disposisi gratitude yang tinggi. (3) Sebanyak 21 odapus melaporkan subjective well-being yang tinggi.
\end{abstract}

Kata Kunci: lupus, gratitude, Psikologi Positif, subjective well-being, Syamsi Dhuha Foundation

\section{Pendahuluan}

Penyakit systemic lupus erythematosus (SLE) termasuk ke dalam salah satu chronic illness yang menyerang seluruh tubuh atau sistem internal manusia. Dalam ilmu imunologi atau kekebalan tubuh, penyakit ini adalah kebalikan dari kanker atau HIV/AIDS. Lupus disebut sebagai autoimmune disease (kekebalan tubuh yang berlebihan) yang dapat menyebabkan banyak kerusakan pada sendi, pembuluh darah, kulit, dan organ dalam. Orang penderita SLE disebut dengan Odapus (Permata, 2014).

Lupus eritematosus sistemik (systemic lupus erythematosus) merupakan penyakit inflamasi autoimun kronis dengan etiologi yang belum diketahui. Memiliki manifestasi klinis, perjalanan penyakit, dan prognosis yang sangat beragam. Hal inilah 
yang membuat tata laksana penyakit ini dapat keliru, disebabkan diagnosisnya yang sangat bergantung pada kompetensi dokter yang menangani. Penyakit ini memiliki angka kematian yang cukup tinggi, hampir 5 kali lebih tinggi dibandingkan populasi umum. Faktor genetik, imunologik dan hormonal serta lingkungan diduga berperan dalam patofisiologi SLE. Kekeliruan dalam mengenali penyakit ini sering terjadi (Perhimpunan Reumatologi Indonesia, 2011). Para odapus harus berobat sepanjang hidupnya, disebabkan antibodi ini tidak lagi berfungsi untuk menyerang virus, kuman atau bakteri yang masuk ke dalam tubuh, tetapi justru menyerang sel dan jaringan tubuhnya sendiri.

Berdasarkan data yang dikemukakan oleh Zubairi (dalam Prasetyo dan Kustanti, 2014), setiap tahun sekitar 5-100 orang dapat terkena systemic lupus erythematosus yang menyebabkan kematian. Berdasarkan data dari Yayasan Lupus Indonesia, jumlah penderita systemic lupus erythematosus di Indonesia terus meningkat. Pada tahun 2010, terdapat jumlah penderita systemic lupus erythematosus di Indonesia secara tepat belum diketahui tetapi diperkirakan telah meningkat dari 12.700 jiwa pada 2012 menjadi 13.300 jiwa per April 2013. (Mardiani, dalam Paramita dan Margaretha, 2013).

Menurut data Yayasan Lupus Indonesia, rentang umur terjangkitnya systemic lupus erythematosus penderita adalah antara 15-45 tahun. Sebagian besar penderita SLE adalah wanita dewasa awal yaitu sebanyak $90 \%$, sementara $10 \%$ sisanya diderita oleh laki-laki dan anakanak (Kulczycka, Sysa-Jędrzejowska, dan Robak, 2011; Perhimpunan Reumatologi Indonesia, 2011; Maruli, dalam Paramita dan Margaretha, 2013).

Sampai saat ini belum terdapat data epidemiologi SLE yang mencakup semua wilayah Indonesia. Data tahun 2002 di RSUP Cipto Mangunkusumo (RSCM) Jakarta, didapatkan $1.4 \%$ kasus SLE dari total kunjungan pasien di poliklinik
Reumatologi Penyakit Dalam, sementara di RS Hasan Sadikin Bandung terdapat 291 Pasien SLE atau $10.5 \%$ dari total pasien yang berobat ke poliklinik reumatologi selama tahun 2010 (Perhimpunan Reumatologi Indonesia, 2011).

Di Kota Bandung sendiri, terdapat 2 yayasan yang peduli terhadap para odapus, yaitu Yayasan Lupus Indonesia Cabang Bandung dan Syamsi Dhuha Foundation. Namun, dari tahun ke tahun, Syamsi Dhuha Foundation merupakan yayasan lupus di Bandung yang paling sering terdengar gaungnya hingga ke TV swasta nasional, bahkan meraih berbagai penghargaan. Misalnya saja, Danamon Award 2010 sebagai penghargaan di tingkat nasional bagi semangat dari para volunteer, pendukung, maupun odapus. Terdapat pula penghargaan dalam level internasional, seperti Sasakawa Health Prize 2012 untuk Syamsi Dhuha Foundation, sebagai jasa yayasan telah menyebarkan kesadaran tentang penyakit lupus.

Syamsi Dhuha Foundation didirikan pada awal tahun 2004 oleh seorang penderita lupus yaitu Dra. Dian W. Syarief dengan dibantu suaminya Ir. Eko. P. Pratomo, MBA. Syamsi Dhuha berusaha merangkul sesama odapus, terutama yang ada di sekitar Bandung dan bercita-cita untuk memberikan kesempatan pada odapus untuk mensyukuri segala karunia yang telah Allah berikan dengan melakukan berbagai aktivitas yang dapat bermanfaat bagi dirinya sebagai pribadi sekaligus juga bagi orang lain.

Syamsi Dhuha Foundation ini memiliki beragam kegiatan yang sangat unik yang diperuntukkan bagi para odapus, serta rutin dilaksanakan setiap minggunya. Setiap hari Senin, para odapus mengikuti kelas yoga. Pada hari Selasa mereka memiliki English Club Conversation. Pada hari Rabu, para odapus yang menggeluti bidang entrepreneurship berdiskusi untuk mengembangkan bisnisnya. Pada hari Kamis, mereka biasanya berlatih musik bersama. Para odapus tersebut dapat memilih 
kegiatan mana yang cocok dengan mereka, sesuai dengan bakat dan minat masingmasing. Menurut para odapus, berbagai aktivitas tersebut dianggap sangat bermanfaat, sebab mereka memiliki banyak kesempatan untuk bertukar pikiran, pengalaman, dan perasaan baik mengenai lupus maupun hal-hal lain dalam hidup mereka.

Selain itu, para odapus juga melakukan kegiatan keagamaan bersama, di mana setiap hari mereka shalat berjamaah. Sedangkan pada hari Sabtu, mereka mengadakan tafakkur bersama, dengan topik-topik tertentu yang dianggap dapat memotivasi odapus untuk semakin semangat dalam menjalani kehidupan.

Sesuai dengan data di berbagai jurnal, odapus di Syamsi Dhuha Foundation pun paling banyak adalah para wanita yang berusia 18 hingga 40 tahun. Lupus merupakan penyakit yang berbeda dengan penyakit-penyakit kronis lainnya (kardiovaskuler, metabolik, urogenital, digestif, pernafasan, dan muskuloskeletal) yang seringkali dialami oleh lansia, di mana prevalensi penyakit kronis pada lansia besarnya mencapai 87,3\% (Yennya dan Herwana, 2006). Artinya, ketika seseorang sedang dituntut untuk mengembangkan kompetensi, memiliki banyak peran dalam kehidupan, dan memiliki produktivitas yang tinggi melalui berbagai pendidikan dan pekerjaan (Glover, 2000), para odapus ini mengalami hambatan terkait berbagai aspek dalam hidupnya disebabkan penyakit lupus, baik secara ekonomi, fisik, psikis, maupun sosial.

Beragam hambatan tersebut meliputi, mahalnya obat yang harus ditebus yang mencapai angka puluhan juta rupiah, kondisi tubuh yang mudah sekali lelah, sakit sendi dan otot yang signifikan (fibromyalgia), larangan untuk terpapar sinar matahari secara langsung, perubahan pada body image sebagai efek samping dari penyakitnya maupun obat-obatan yang dikonsumsi, misalnya menyebabkan moon face atau bertambahnya berat badan, bercak-bercak kemerahan yang muncul pada wajah, rambut rontok, bersisik dan mulai mengelupas, sariawan di sekitar mulut, rasa nyeri pada persendian tangan dan kaki, sampai pada bagian tubuh yang sulit untuk digerakkan, dan memar-memar pada tubuh yang muncul secara tiba-tiba.

Menurut Maruli (Paramita dan Margaretha, 2013), odapus harus menerima konsekuensi akumulasi kerusakan organ tubuh dari imun tubuh yang merusak organorgan tubuhnya serta obat-obatan yang dikonsumsinya. Efek samping dari obat lupus yang berupa kortikotreroid sangatlah berat. Mulai dari rambut rontok, berat badan bertambah, sakit lambung, mulut kering, menurunnya fertilitas, meningkatkan resiko kanker, mual-mual. Long term effect dari obat tersebut dapat meningkatkan resiko kanker, osteoporosis, diabetes, katarak, dan darah tinggi.

Sebagian besar dari para odapus di Syamsi Dhuha Foundation memilih untuk tidak menikah, sebab mengetahui bahwa lupus merupakan penyakit menurun. Oleh karena itu, sebagian besar anggota Syamsi Dhuha Foundation yaitu wanita dewasa awal berusia 18-40 tahun memilih untuk tidak menikah karena alasan tersebut. Padahal, salah tugas perkembangan masa dewasa awal adalah mengembangkan mature relationship dalam rangka mencapai intimacy dan commitment (Glover, 2000). Sesuai dengan budaya Indonesia, yang dikatakan sebagai mature relationship tentunya adalah pernikahan. Artinya, terdapat tugas perkembangan yang tidak tercapai oleh sebagian besar odapus.

Dengan berbagai keadaan yang memberatkan baik secara ekonomi, fisik, psikis, maupun sosial, tentu saja merupakan hal yang wajar jika seseorang yang memiliki penyakit lupus, akan merespon secara negatif. Hal ini sejalan dengan wawancara yang dilakukan oleh peneliti terhadap 8 orang odapus di Syamsi Dhuha Foundation.

Dua orang odapus mengatakan bahwa mereka mengalami beberapa kali periode 
depresi di mana mereka tidak mau keluar rumah untuk beraktivitas dan memilih untuk mengunci diri di kamar untuk menangis ataupun melamun. Artinya, dua orang tersebut menunjukkan afek negatif, karena dialaminya beberapa periode depresi ketika mengalami sakit lupus. Selain itu, salah satu dari mereka mengatakan bahwa ketika ia merasa sangat sedih atau marah, ia merasa bahwa dirinya adalah ciptaan Tuhan yang salah. Odapus tersebut juga merasa tidak puas dengan hidupnya, yang mana mereka mengatakan bahwa hidup ini tidak adil sebab mereka harus ditimpa sakit seberat lupus. Mereka seringkali bertanyatanya, "Mengapa harus aku?" dan "Mengapa ini terjadi?" kepada diri sendiri. Menurut mereka, sakit lupus membuat mereka tidak mampu melakukan banyak hal yang selama sehat mampu mereka lakukan tanpa kendala, seperti beraktivitas di bawah sinar matahari.

Namun, dari hasil observasi yang dilakukan peneliti selama beberapa minggu, respon berbeda ditunjukkan oleh 6 orang odapus yang lainnya. Mereka menunjukkan ekpresi afek yang positif selama berkegiatan dari Senin hingga Sabtu di Syamsi Dhuha Foundation, yang mana mereka seringkali tersenyum, bercanda, dan tertawa dengan sesama odapus.

Mereka mengatakan bahwa hidup mereka bahagia, sebab banyak hal menyenangkan dan berharga di dalam hidup mereka meski ditimpa sakit seberat lupus. Menurut mereka, banyak hikmah yang dapat diambil yang tidak akan didapatkan tanpa adanya sakit lupus. Mereka mengatakan bahwa, jika waktu bisa diputar, mereka akan memilih untuk tetap sakit lupus, sebab lupus membawa perubahan besar bagi diri mereka ke arah positif. Mereka mengatakan bahwa sekarang dirinya menjadi lebih dekat dengan Tuhan Yang Maha Esa, menjadi tidak sepemarah dulu, dan mengatakan bahwa sekarang dirinya menjadi lebih menghargai kenikmatan-kenikmatan kecil di dalam hidup, termasuk nikmat sehat.
Para odapus tersebut mengatakan bahwa banyak nikmat yang ia rasakan, seperti ekonominya mencukupi, masih bisa melanjutkan kuliah, dan dukungan yang luar biasa dari teman dan keluarga. Meski begitu, 2 di antara 6 orang tersebut mengatakan bahwa terkadang kesehatan menghambat mereka dalam melakukan berbagai aktivitas, sedangkan 4 orang sisanya mengatakan sama sekali tidak ada hambatan dalam melakukan aktivitas apapun. Menurut 4 orang tersebut, yang terpenting adalah pintar mengatur diri agar jangan sampai kelelahan sehingga penyakitnya menjadi flare-up. Data tersebut menunjukkan bahwa, sebagian besar odapus mereka merasa puas dengan keadaan hidup mereka saat ini.

Dari data di atas, terlihat bahwa sebagian besar odapus seringkali tersenyum, tertawa, bercanda, dan mengatakan bahwa hidup mereka bahagia sebab banyak hal menyenangkan di dalam hidup mereka, merasa puas dengan hidup mereka yang sekarang, dan tidak merasa menyesal dengan takdir yang ada yaitu menderita lupus, sebab banyak kebaikan yang dapat mereka ambil dari sakit lupus. Ketika seseorang menunjukkan ekspresi afek yang tinggi, menunjukkan kepuasaan terhadap hidupnya secara keseluruhan maupun dalam aspek-aspek tertentu di dalam hidupnya, artinya seseorang tersebut memiliki subjective well-being yang tinggi (Diener, Suh, Lucas, dan Smith, 1999).

Berbagai penelitian menunjukkan bahwa orang yang terganggu domain kesehatannya, yang mana ia memiliki chronic illness atau disabilities (CID) seringkali memiliki persepsi kepuasan hidup yang rendah dibanding dengan mereka yang tidak memiliki CID (Dijkers, 1999: Krause, 1992 dalam Kim, Berven, Chan, Gonzalez, Miller, dan Keck, 2011). Artinya, merupakan hal yang luar biasa unik ketika 6 orang odapus memiliki persepsi terhadap hidup yang bahagia dan menunjukkan afek positif yang tinggi, 
meski mereka ditimpa penyakit lupus yang termasuk ke dalam penyakit kronis.

Berbagai alasan diungkapkan para odapus bahwa menurut mereka hidup mereka tetap sama bahagianya seperti sebelum terkena sakit lupus. Mereka mengatakan bahwa Tuhan memberikan banyak hal yang berharga di luar sakitnya tersebut. Menurut para odapus, semenjak menderita lupus, ia semakin sering mengingat nikmat yang Tuhan berikan, baik dari segi ekonomi, kesehatan, dan akademik.

Tiga odapus mengatakan bahwa keluarga dan teman yang selalu memberi support adalah kenikmatan yang sangat berharga. Tiga odapus lainnya berkata bahwa kehidupan akademiknya yang baik adalah hal yang paling membuatnya semangat untuk mengejar cita-citanya di masa depan. Hal tersebut menunjukkan, bahwa para odapus sangat menghargai berbagai kenikmatan yang ada di dalam hidup mereka.

Menurut keenam odapus tersebut, mereka harus belajar untuk berteman dengan penyakit lupus, menerima lupus sebagai bagian dari mereka, bukan malah membenci kemudian berusaha memerangi penyakitnya tersebut. Hal ini pula yang dikatakan Ibu Dian, selaku pendiri Syamsi Dhuha Foundation, dimana odapus harus berteman dengan lupus, menerima penyakit tersebut sebagai bagian dari dirinya, sehingga mampu berdamai dengan penyakitnya.

Para odapus memiliki berbagai prestasi. Diantaranya, terdapat odapus yang menjuarai lomba model muslimah dan lomba story telling, kuliah S2 di Jerman, memiliki bisnis florist, dan memiliki usaha travel yang omzetnya mencapai puluhan juta rupiah setiap bulannya. Para odapus ini sependapat bahwa semua prestasi yang mampu dicapai mereka sejauh ini, meski dengan adanya sakit kronis yang membuat mereka harus berobat seumur hidup, tidak mampu dicapai tanpa campur tangan dari Tuhan Yang Maha Esa.
Dengan limpahan nikmat yang mereka alami tersebut, mereka mengatakan bahwa sangat perlu untuk menunjukkan penghargaan terhadap Tuhan maupun orang-orang di sekitar mereka. Seorang odapus mengaku sering merenungkan nikmat yang ia rasakan setiap selesai shalat. Kepada Tuhan, mereka seringkali berkata, "Alhamdulillah", sedangkan kepada temanteman dan keluarga biasanya mereka memeluk, tersenyum, dan terkadang juga mengucapkan terima kasih secara verbal. Hal tersebut menunjukkan bahwa selain para odapus merasa bahwa kesuksesannya tidak lepas dari campur tangan Tuhan Yang Maha Esa dan bantuan berbagai pihak, mereka juga mengekspresikan rasa terimakasih melalui berbagai perilaku. Mereka mengatakan bahwa mereka banyak mengingat nikmat yang Allah berikan setiap hari, melalui doa yang mereka panjatkan.

Namun, menurut dua odapus, terkadang mereka membanding-bandingkan prestasi mereka dengan orang yang sehat, kemudian muncul perasaan bahwa sebenarnya mereka mampu berbuat lebih jika tidak diberi sakit lupus. Odapus tersebut juga merasa bahwa ia adalah ciptaan Tuhan yang salah, sebab harus ditimpa sakit seberat lupus. Namun, mereka berusaha untuk membuang perasaan tersebut jauh-jauh, dengan cara mengingatingat kenikmatan-kenikmatan yang telah diberikan Tuhan.

Terdapat pula odapus lainnya yang seringkali menganggap ibunya cerewet ketika ia dinasehati mengenai penyakitnya. Menurutnya, support keluarga memang besar, namun ketika kondisi emosinya sedang tidak stabil, dia seringkali menyalahkan hal-hal lain di dalam hidupnya, seperti takdir, dirinya sendiri, bahkan teman dan keluarganya. Hal ini menunjukkan bahwa odapus tersebut kurang menghargai kebaikan yang dilakukan oleh orang lain terhadap dirinya.

Terdapat pula odapus yang meraih UN tertinggi ke-4 saat di SMA, odapus lainnya 
mampu lulus SMK jurusan administrasi keuangan. Namun, para odapus tersebut seringkali membandingkan dirinya dengan teman-temannya yang sehat dan merasa bahwa prestasi yang mereka capai tidak ada artinya dibandingkan dengan prestasi teman-temannya. Artinya, meski odapus tersebut mampu mencapai beragam prestasi di bidang akademik di tengah sakit lupus yang dideritanya, mereka tetap merasa teman-temannya yang sehat lebih baik dibanding dirinya.

Dari data tersebut, terlihat sebagian odapus menganggap bahwa meskipun mereka ditimpa penyakit seberat lupus, masih banyak kebaikan yang ada di dalam hidupnya yang diberikan oleh Tuhan maupun orang-orang di sekitarnya. Ketika seseorang menganggap bahwa kebaikan di dalam hidupnya adalah merupakan hasil dari campur tangan pihak-pihak lain di sekitarnya, berarti orang tersebut memiliki gratitude. Gratitude adalah emosi yang seseorang rasakan ketika dia menganggap bahwa sesuatu yang baik telah terjadi kepadanya dan dia menyadari bahwa pihak lain bertanggung jawab atas kebaikan tersebut. Seseorang yang memiliki gratitude trait harus memiliki karakteristik sense of abundance, appreciation of simple pleasures, dan social appreciation (Watkins, 2013).

Dari hasil wawancara dan observasi awal, gambaran subjective well-being pada wanita odapus dewasa awal di Syamsi Dhuha Foundation masih sangat beragam, yang mana terdapat odapus yang menunjukkan afek negatif seperti depresi dan merasa hidupnya tidak adil, namun terdapat pula odapus yang banyak menunjukkan afek positif dan merasa hidupnya semakin bahagia sejak sakit lupus.

Begitu pula dengan gambaran gratitude trait, dimana terdapat mereka yang sudah memiliki gratitude trait yang tinggi sebab merasakan banyaknya hal berharga dalam hidupnya di luar sakit lupus (sense of abundance), menghargai hal-hal kecil di dalam hidup, seperti matanya masih mampu melihat (appreciation of simple pleasures), dan menghargai kebaikan pihak lain seperti Tuhan Yang Maha Esa, keluarga, dan teman dalam pencapaian kesuksesannya (appreciation of others). Namun, terdapat pula mereka yang menganggap bahwa lupus membuat dirinya merasa sebagai ciptaan Tuhan yang salah, prestasinya dianggap tidak berharga dibandingkan teman-temannya, dan menganggap orang tuanya cerewet ketika menasehati mengenai sakitnya. Artinya, terdapat pula odapus yang memiliki sense of abundance, appreciation of simple pleasures, dan appreciation of others yang rendah.

Dalam berbagai jurnal (Watkins, Woodward, Stone, dan Kolts, 2003; dalam Watkins, 2013; Brunner, Watkins, dan Webber, 2010; Wood, 2008; dalam Ruini dan Vescovelli, 2013; McCullough, Emmons, dan Tsang, 2002), seharusnya terdapat hubungan yang positif di antara kedua variabel tersebut, yang mana ketika seseorang memiliki gratitude trait yang tinggi, maka subjective well-being akan tinggi pula. Hal ini terlihat dari sebagian besar odapus yang mengatakan bahwa banyak sekali hal-hal berharga di dalam hidupnya yang membuat mereka merasa bersyukur. Odapus tersebut juga mengatakan bahwa hidupnya malah menjadi sangat bahagia setelah lupus, sebab banyak hikmah yang mampu mereka ambil.

Namun, terdapat beberapa odapus yang merasakan banyak hal berharga dalam hidupnya di luar sakit lupus, seperti pencapaian akademik yang baik. Namun ternyata mereka terkadang mengalami depresi, karena membanding-bandingkan diri dengan orang lain. Ketika periode depresi itu muncul, mereka memilih untuk diam di rumah, melamun, bahkan menolak untuk beraktivitas.

Selanjutnya, terdapat odapus yang sering mengekspresikan terimakasih kepada teman dan keluarga dengan cara memeluk atau bentuk verbal. Tetapi, ia 
mengatakan bahwa dirinya adalah ciptaan Tuhan yang salah, sebab harus menderita penyakit seberat lupus.

Dua odapus lainnya juga mengatakan bahwa mereka semakin menghargai hal-hal kecil di dalam hidup, seperti matanya masih mampu melihat. Namun ternyata, mereka mengatakan bahwa kesehatan mereka yang mudah lelah dan tidak boleh terkena sinar matahari langsung membuat mereka terhambat dalam melakukan berbagai aktivitas.

Dari uraian di atas, adalah hal yang sangat menarik ketika penderita lupus dengan berbagai keadaan berat yang dialaminya, masih terdapat odapus yang diduga tetap mampu menunjukkan ciri-ciri gratitude dan subjective-well being, meski secara teoretis merupakan hal yang mustahil terjadi. Selain itu, dari hasil wawancara, terlihat bahwa terdapat hubungan yang tidak konsisten antara gratitude dan subjective well-being, yang mana terdapat beberapa odapus yang sudah menunjukkan ciri-ciri gratitude trait yang tinggi, namun diduga masih memiliki subjective well-being yang rendah, padahal menurut berbagai jurnal, seharusnya seseorang yang memiliki gratitude yang tinggi, akan memiliki subjective well-being yang tinggi pula. Oleh karena itu, peneliti tertarik untuk meneliti keeratan hubungan gratitude dan subjective well-being pada odapus wanita dewasa awal di Syamsi Dhuha Foundation. Dengan demikian penelitian ini dilakukan untuk memperoleh data empirik mengenai masing-masing variabel yaitu gratitude trait maupun subjective well-being pada odapus wanita dewasa awal di Syamsi Dhuha Foundation, serta keeratan hubungan antara kedua variabel tersebut.

\section{Metode Penelitian}

\section{Hipotesis Penelitian}

Hipotesis dalam penelitian ini adalah semakin tinggi gratitude maka subjective well-being pada odapus wanita dewasa awal di Syamsi Dhuha Foundation akan semakin tinggi pula.

\section{Rancangan Penelitian}

Penelitian mengenai hubungan gratitude dengan subjective well-being pada odapus wanita dewasa awal di Syamsi Dhuha Foundation ini merupakan penelitian yang akan dibahas secara korelasional. Penelitian korelasi atau korelasional adalah suatu penelitian untuk mengetahui hubungan dan tingkat hubungan antara dua variabel atau lebih tanpa ada upaya untuk memengaruhi variabel tersebut sehingga tidak terdapat manipulasi variabel (Fraenkel dan Wellen, 2008).

Pada penelitian ini, variabel gratitude akan dilihat hubungannya dengan variabel subjective well-being. Korelasi zero (0) mengindikasikan tidak ada hubungan. Korelasi positif mengindikasikan bahwa semakin tinggi skor pada suatu variabel, semakin tinggi pula skor pada variabel lain atau sebaliknya (Emzir, 2009:48).

Tujuan penelitian korelasional menurut Suryabrata (1994:24) adalah untuk mendeteksi sejauh mana variasi-variasi pada suatu faktor berkaitan dengan variasivariasi pada satu atau lebih faktor lain berdasarkan pada koefisien korelasi.

\section{Subjek Penelitian}

Populasi pada penelitian ini adalah sebanyak 30 odapus di Syamsi Dhuha Foundation dengan karakteristik sebagai berikut;

Wanita pengidap lupus usia dewasa awal (18-40 tahun), karena penyakit lupus seringkali diidap oleh wanita muda (Kulczycka dkk., 2011), dimana menurut data Yayasan Lupus Indonesia, 90 persen diantaranya adalah perempuan muda dan 10 persen diderita oleh laki-laki dan anakanak (Maruli, dalam Paramita dan Margaretha, 2013).

Anggota aktif dari Syamsi Dhuha Foundation. 


\section{Alat Ukur}

Alat ukur untuk mengukur gratitude pada penelitian ini adalah Gratitude, Resentment, dan Appreciation Tes (GRATR) (Watkins, Woodward, Katharane, Stone, Tamara, dan Kolts, 2002), yang melalui berbagai uji validitas dan reliabilitas memiliki properti psikometrik yang adekuat, dengan reliabilitas internal (alpha = 0.92) (Watkins, Porter, dan Curtis, 1996; Watkins, Porter, dan Miller, 1997; dalam Emmons dan McCullough, 2004) sebanyak 44 item. GRAT-R (2002) ini kemudian dimodifikasi oleh peneliti, sesuai dengan keperluan penelitian.

Sementara itu, Diener, Oishi, dan Lucas (2012) menyatakan bahwa tinggi atau rendah derajat subjective well-being pada seseorang terlihat dari skor agregat komponen afektif dan kognitif. Oleh karena itu, alat ukur subjective well-being pada penelitian ini akan terdiri dari 3, yakni Scale of Positive and Negative Experience (SPANE) (2009) untuk mengukur komponen afektif. Sedangkan, Satisfaction With Life Scales (1987) dan Domain Satisfaction Scales (2007) digunakan untuk mengukur komponen kognitif.

Alat ukur untuk mengukur komponen pleasant dan unpleasant affect untuk subjective well-being adalah berupa dari Scale of Positive and Negative Experience (SPANE) (Diener dkk., 2012), yaitu SPANE-P sebanyak 6 item dan SPANE-N sebanyak 6 item. SPANE-P dan SPANE-N saling berkorelasi secara negatif sebesar $\mathrm{r}=$ -.60 ( $\mathrm{N}=682, \mathrm{p}>.001)$. SPANE-B adalah total dari SPANE-P dikurangi SPANE-N, yang memiliki reliabilitas (0.89) dan validitas $(0.66, \mathrm{~N}=502)$ yang tinggi (Diener dkk., 2012). SPANE kemudian diterjemahkan ke dalam Bahasa Indonesia oleh peneliti.

Alat ukur untuk mengukur life satisfaction dari subjective well-being adalah berupa translasi ke Bahasa Indonesia dari Satisfaction with Life $(S W L S)$ (Diener, 1987) sebanyak 5 item. Reliabilitas dari alat ukur ini adalah excellent (Cronbach's $\alpha=0.83-0.92$ ) (Dijkers 1999; Post, van Leeuwen, van Koppenhagen, dan de Groot, 2012; Geyh dkk., 2010; Hitzig, Romero, Noreau, dan Craven, 2012; dalam Krause, Saunders, Reed, Coker, Zhai, dan Jhonson, 2009). Sementara itu validitas alat ukur ini adalah excellent (Spearman's $\alpha=0.89$ ) (Dijkers 1999; Scherer dan Cushman 2001; Post dkk., 2012; Richardson dan Richards 2008; Hitzig dkk., 2012; Krause dkk., 2009).

Uji validitas alat ukur menggunakan korelasi rank spearman, menggunakan taraf signifikan $\alpha=0.05$ dan $\alpha=0.01$. Berdasarkan critical values of the spearman's ranked correlation coefficient (r)s (Zar, 1984), jika $\mathrm{n}=30$ maka critical values yang didapat adalah 0.362 dan 0.467 . Item yang valid dapat digunakan untuk penelitian selanjutnya. Dari hasil uji validitas alat ukur gratitude, didapatkan hasil bahwa 41 dari 44 item alat ukur dinyatakan valid, dimana item nomor 11 , 26, dan 29 dinyatakan tidak valid. Lima dari 5 item Satisfaction With Life Scales yang telah diterjemahkan ke dalam Bahasa Indonesia oleh peneliti dinyatakan valid. Tujuh dari 7 item Domain Satisfaction Scales yang telah diterjemahkan ke dalam Bahasa Indonesia oleh peneliti dinyatakan valid. Sementara itu, 6 dari 6 item SPANE$P$ yang telah diterjemahkan ke dalam Bahasa Indonesia oleh peneliti dinyatakan valid. Terakhir, 6 dari 6 item SPANE-N yang telah diterjemahkan ke dalam Bahasa Indonesia oleh peneliti dinyatakan valid.

Uji reliabilitas menggunakan teknik alpha cronbach dengan bantuan aplikasi SPSS 22.0. Hasil uji reliabilitas GRAT-R sebanyak 41 item valid menggunakan uji alpha cronbach didapatkan sebesar 0,975. Artinya, diketahui bahwa GRAT-R memiliki derajat reliabilitas yang tinggi sekali. Hasil uji reliabilitas Satisfaction With Life Scales sebanyak 5 item valid menggunakan uji alpha cronbach didapatkan sebesar 0,789. Artinya, diketahui bahwa Satisfaction With Life Scales memiliki derajat reliabilitas yang tinggi. Hasil uji reliabilitas 
Domain Satisfaction Scales sebanyak 7 item valid menggunakan uji alpha cronbach didapatkan sebesar 0,699. Artinya, reliabilitas Domain Satisfaction Scales dinyatakan tinggi. Hasil uji reliabilitas SPANE-P sebanyak 6 item valid menggunakan uji alpha cronbach didapatkan sebesar 0,837. Artinya, reliabilitas SPANE-P dinyatakan tinggi sekali. Hasil uji reliabilitas SPANE-P sebanyak 6 item valid menggunakan uji alpha cronbach didapatkan sebesar 0,885 . Artinya, reliabilitas SPANE-N dinyatakan tinggi sekali.

\section{Analisis Data}

Data dari kuesioner dikumpulkan kemudian diolah untuk menguji hipotesis yang telah dibuat oleh peneliti. Pertama, dilakukan skoring terhadap setiap kuesioner sesuai dengan respon yang dijawab oleh subjek penelitian. Setelah itu, data-data dimasukkan dan di-coding sesuai dengan jenis item, baik favorable maupun unfavorable. Setelah itu, dilakukan analisis data secara manual dan menggunakan bantuan Statistic Package for Social Science (SPSS) versi 22. Teknik yang digunakan adalah;

Uji Normalitas. Sebelum data tiap variabel diolah, dilakukan uji normalitas data untuk melihat apakah data yang didapat adalah data normal atau tidak. Jika data normal, maka kriteria variabel tersebut akan dibuat berdasarkan kriteria kelompok. Sementara itu, jika data tidak normal, maka pembanding akan menggunakan kriteria mutlak. Uji normalitas yang dilakukan adalah uji Shapiro-Wilk, sebab $\mathrm{n}<50$. Data dikatakan normal jika $p \geq 0,05$.

Statistik Deskriptif. Dalam menganalisis data yang telah terkumpul dilakukan beberapa langkah yaitu menentukan jumlah item, menentukan skor minimum, dengan rumus ( $\mathrm{x} 1=$ jumlah item $\mathrm{x}$ skor nilai terrendah), menentukan skor maksimum, dengan rumus $(\mathrm{x} 2=$ jumlah item $\mathrm{x}$ skor nilai tertinggi), mencari rentang skor ( $R$ ) dengan rumus $\mathrm{R}=\mathrm{x} 2-\mathrm{x} 1$, menentukan jarak kategori dengan rumus $\mu$ $=\mathrm{R}: 2$, menghitung frekuensi, sebagai berikut: rendah dan tinggi.

Setelah diuji secara statistik, kemudian dideskripsikan tingkat gratitude dan subjective well-being pada wanita dewasa awal di Syamsi Dhuha Foundation berdasarkan kategori yang ada.

Rank spearman correlation. Melalu teknik analisis ini, dapat diketahui hubungan antara dua variabel ordinal nonparametrik yang diteliti, dengan bantuan SPSS 22.0.

\section{Hasil Penelitian dan Pembahasan}

\section{Hasil Penelitian}

Data Demografi. Berdasarkan tabel, dapat dilihat bahwa dalam kegiatan keagamaan, hanya 4 orang yang tidak mengikuti kegiatan keagamaan, sedangkan sisanya mengikuti tafakkur ataupun pengajian. Artinya, sebagian besar odapus di Syamsi Dhuha Foundation mengikuti kegiatan keagamaan. Pada status pernikahan, terlihat bahwa hanya 5 orang yang menikah, sementara sisanya, yaitu 25 orang belum menikah. Artinya, sebagian besar odapus di Syamsi Dhuha Foundation belum menikah. Pada status kesehatan, terlihat bahwa 18 orang odapus sedang mengalami remisi, sedangkan 12 orang sisanya sedang mengalami flare. Artinya, sebagian besar odapus di Syamsi Dhuha Foundation sedang mengalami fase remisi penyakitnya.

Gratitude dan Subjective Well-Being. Perhitungan korelasi antara skor total gratitude dan subjective well-being pada odapus wanita dewasa awal di Syamsi Dhuha Foundation dilakukan dengan metode rank spearman, disebabkan data yang didapatkan merupakan data ordinal.

Tabel 2 menunjukkan nilai korelasi (r) adalah 0.875 dan nilai $\mathrm{p}=0.000$, signifikan pada level of significant 0.01 (one-tailed). Dari data di atas, dapat disimpulkan bahwa terdapat korelasi positif yang signifikan kuat yaitu sebesar $\mathrm{r}=0,875$, di antara variabel gratitude dan subjective well-being 
pada odapus wanita dewasa awal di Syamsi Dhuha Foundation. Artinya, jika odapus memiliki gratitude yang tinggi, maka odapus akan memiliki subjective well-being yang tinggi pula.

Untuk mengetahui lebih lanjut mengenai gambaran hubungan antara fasetfaset dalam gratitude trait dan subjective well-being, dilakukan analisis dengan menggunakan uji spearman.
Dari tabel 3, diketahui bahwa terdapat korelasi positif signifikan yang kuat di antara faset sense of abundance dan subjective well-being, di mana $\mathrm{r}=0,899$. Artinya, jika seseorang memiliki faset sense of abundance yang tinggi, maka ia akan memiliki subjective well-being yang tinggi pula.

Tabel 1

Gambaran Umum Subjek Penelitian

\begin{tabular}{cccc}
\hline \multicolumn{2}{c}{ Data Demografi } & Frekuensi & Presentase \\
\hline Kegiatan Keagamaan & Ya & 26 & $86.66 \%$ \\
& Tidak & 4 & $13.34 \%$ \\
Status Pernikahan & Menikah & 5 & $16.67 \%$ \\
& Belum Menikah & 25 & $83.33 \%$ \\
Status Kesehatan & Remisi & 18 & $60 \%$ \\
& Flare & 12 & $40 \%$ \\
\hline
\end{tabular}

Tabel 2

Korelasi Gratitude dengan Subjective Well-Being

\begin{tabular}{|c|c|c|c|c|}
\hline & & & GRAT & $S W B$ \\
\hline \multirow[t]{6}{*}{ Spearman's rho } & \multirow[t]{3}{*}{ GRAT } & Correlation Coefficient & 1,000 & $875^{* *}$ \\
\hline & & Sig. (1-tailed $)$ & . &, 000 \\
\hline & & $N$ & 30 & 30 \\
\hline & \multirow[t]{3}{*}{$S W B$} & Correlation Coefficient &, $875^{* *}$ & 1,000 \\
\hline & & Sig. (1-tailed $)$ & ,000 & . \\
\hline & & $N$ & 30 & 30 \\
\hline
\end{tabular}

**. Correlation is significant at the 0.01 level (1-tailed).

Tabel 3

Hubungan antara Sense of Abundance dan Subjective Well-Being

\begin{tabular}{lllll}
\hline & & SENSE & SWB \\
\hline Spearman's rho & SENSE & Correlation Coefficient & 1,000 &, $899^{* *}$ \\
& Sig. (1-tailed) & $\cdot$ &, 000 \\
& $N$ & 30 & 30 \\
\multirow{2}{*}{ SWB } & Correlation Coefficient &, $899^{* *}$ & 1,000 \\
& Sig. (1-tailed) &, 000 &. \\
& $N$ & 30 & 30 \\
\hline
\end{tabular}

**. Correlation is significant at the 0.01 level (1-tailed). 
Hubungan Gratitude Dan Subjective Well-Being Odapus Wanita Dewasa Awal di Syamsi Dhuha Foundation Bandung (Nadia Felicia Mahardhika, Lilim Halimah)

Tabel 4

Hubungan antara Appreciation of Simple Pleasures dan Subjective Well-Being

\begin{tabular}{lllll}
\hline & & SIMPLE & SWB \\
\hline Spearman's rho & SIMPLE & Correlation Coefficient & 1,000 &, $752^{* *}$ \\
& Sig. (1-tailed) & $\cdot$ &, 000 \\
& $N$ & 30 & 30 \\
& \multirow{2}{*}{ SWB } & Correlation Coefficient &, $752^{* *}$ & 1,000 \\
& Sig. (1-tailed) &, 000 &. \\
& $N$ & 30 & 30 \\
\hline
\end{tabular}

**. Correlation is significant at the 0.01 level (1-tailed).

Tabel 5

Hubungan antara Appreciation of Others dan Subjective Well-Being

\begin{tabular}{|c|c|c|c|c|}
\hline & & & OTHERS & $S W B$ \\
\hline \multirow[t]{6}{*}{ Spearman's rho } & OTHERS & Correlation Coefficient & 1,000 &, $766^{* * *}$ \\
\hline & & Sig. (1-tailed $)$ & . & ,000 \\
\hline & & $N$ & 30 & 30 \\
\hline & $S W B$ & Correlation Coefficient &, $766^{* *}$ & 1,000 \\
\hline & & Sig. (1-tailed) &, 000 & . \\
\hline & & $N$ & 30 & 30 \\
\hline
\end{tabular}

**. Correlation is significant at the 0.01 level (1-tailed).

Tabel 6

Persebaran Skor Total Gratitude

\begin{tabular}{ccccc}
\hline Skor total & & Kategori & Frekuensi & Presentase (\%) \\
\hline$<205$ & & Rendah & 3 & $10 \%$ \\
$\geq 205$ & & Tinggi & 27 & $90 \%$ \\
& Total & & 30 & 100 \\
\hline
\end{tabular}

Dari tabel 4, diketahui bahwa terdapat korelasi positif signifikan yang kuat di antara faset appreciation of simple pleasures dan subjective well-being, dimana $\mathrm{r}=0,752$. Artinya, jika seseorang memiliki faset appreciation of simple pleasures yang tinggi, maka ia akan memiliki subjective well-being yang tinggi pula.

Dari tabel 5, diketahui bahwa terdapat korelasi positif signifikan yang kuat di antara faset appreciation of others dan subjective well-being, dimana $\mathrm{r}=0,764$. Artinya, jika seseorang memiliki faset appreciation of others yang tinggi, maka ia akan memiliki subjective well-being yang tinggi pula.

\section{Hasil Pengolahan Data Gratitude}

Kuesioner penelitian gratitude adalah merupakan GRAT-R yang telah diadaptasi oleh peneliti. Keseluruhan alat ukur ini terdiri dari 41 item pernyataan yang valid dari total 44 item. Skor maksimal dan skor minimal ini yang menjadi skor ideal dari kuesioner GRAT-R. Kemudian berdasarkan skor ideal tersebut dijadikan acuan dalam membuat kategori untuk gambaran disposisi gratitude keseluruhan yang dibagi ke dalam dua kategori, yaitu rendah dan 
tinggi. Gambaran umum skor total gratitude subjek penelitian dapat dilihat pada tabel 6.

Data pada tabel 6 menunjukkan bahwa terdapat 3 orang yang memiliki tingkat gratitude rendah dan 27 orang yang memiliki tingkat gratitude trait yang tinggi. Artinya, sebagian besar odapus di Syamsi Dhuha Foundation memiliki gratitude affective trait yang tinggi, artinya, mereka memiliki treshold emosi gratitude yang rendah terhadap berbagai situasi.

\section{Faset Sense of Abundance}

Berdasarkan perhitungan, pada faset sense of abundance, didapatkan hasil sebagai berikut:

Tabel 7

Distribusi Frekuensi Sense of Abundance

\begin{tabular}{cccc}
\hline $\begin{array}{c}\text { Skor } \\
\text { total }\end{array}$ & Kategori & Frekuensi & $\begin{array}{c}\text { Presentase } \\
(\%)\end{array}$ \\
\hline$<90$ & Rendah & 4 & $13.33 \%$ \\
$\geq 90$ & Tinggi & 26 & $86.67 \%$ \\
& Total & 30 & 100 \\
\hline
\end{tabular}

Dari tabel di atas, terlihat bahwa sebagian besar odapus wanita dewasa awal di Syamsi Dhuha Foundation, yaitu sebanyak $86.67 \%$ atau 26 orang memiliki faset sense of abundance yang tinggi, sedangkan, $13.33 \%$ atau 4 orang memiliki sense of abundance yang rendah. Artinya, sebagian besar odapus di Syamsi Dhuha Foundation merasakan banyak kebaikan di dalam hidupnya.

\section{Faset Appreciation of Simple Pleasures}

Berdasarkan perhitungan, pada faset appreciation of simple pleasures didapatkan hasil sebagai berikut:

Tabel 8

Distribusi Frekuensi Appreciation of Simple

Pleasures

\begin{tabular}{cccc}
\hline $\begin{array}{c}\text { Skor } \\
\text { total }\end{array}$ & Kategori & Frekuensi & $\begin{array}{c}\text { Presentase } \\
(\%)\end{array}$ \\
\hline$<75$ & Rendah & 0 & $0 \%$ \\
$\geq 75$ & Tinggi & 30 & $100 \%$ \\
& Total & 30 & 100 \\
\hline
\end{tabular}

Dari tabel di atas, terlihat bahwa sebagian besar odapus wanita dewasa awal di Syamsi Dhuha Foundation, yaitu sebanyak $100 \%$ atau 30 orang memiliki faset appreciation of simple pleasures yang tinggi. Artinya, seluruh odapus di Syamsi Dhuha Foundation menghargai kebaikankebaikan kecil yang ada di sekelilingnya.

\section{Faset Appreciation to Others}

Berdasarkan perhitungan, pada faset appreciation to others didapatkan hasil sebagai berikut:

Tabel 9

Distribusi Frekuensi Appreciation to Others

\begin{tabular}{cccc}
\hline $\begin{array}{c}\text { Skor } \\
\text { total }\end{array}$ & Kategori & Frekuensi & $\begin{array}{c}\text { Presentase } \\
(\%)\end{array}$ \\
\hline$<50$ & Rendah & 4 & $13.33 \%$ \\
$\geq 50$ & Tinggi & 26 & $86.67 \%$ \\
& Total & 30 & 100 \\
\hline
\end{tabular}

Dari tabel di atas, terlihat bahwa sebagian besar odapus wanita dewasa awal di Syamsi Dhuha Foundation, yaitu sebanyak $86.67 \%$ atau 26 orang memiliki faset appreciation to others yang tinggi, sedangkan $13.33 \%$ atau 4 orang memiliki appreciation to others yang rendah. Artinya, sebagian besar odapus di Syamsi Dhuha Foundation menghargai kebaikan yang telah diberikan pihak lain kepada dirinya.

\section{Hasil Pengolahan Data Subjective Well- Being}

Gambaran umum skor total subjective well-being subjek penelitian dapat dilihat pada tabel berikut ini:

Tabel 10

Persebaran Skor Subjective Well-Being

\begin{tabular}{cccc}
\hline $\begin{array}{c}\text { Skor } \\
\text { total }\end{array}$ & Kategori & Frekuensi & $\begin{array}{c}\text { Presentase } \\
(\%)\end{array}$ \\
\hline$<36$ & Rendah & 9 & $30 \%$ \\
$\geq 36$ & Tinggi & 21 & $70 \%$ \\
& Total & 30 & 100 \\
\hline
\end{tabular}

Dari data di atas, terlihat bahwa 21 orang memiliki subjective well-being yang 
tinggi, sedangkan 9 orang sisanya memiliki subjective well-being yang rendah. Artinya, sebagian besar odapus di Syamsi Dhuha Foundation menunjukkan frekuensi ekspresi emosi positif yang tinggi, memiliki kepuasan hidup secara umum yang tinggi, dan memiliki kepuasan terhadap berbagai aspek kehidupan yang tinggi.

\section{Komponen Kognitif}

Berdasarkan perhitungan, pada komponen kognitif subjective well-being, didapatkan hasil sebagai berikut:

Tabel 11

Distribusi Frekuensi Komponen Kognitif

\begin{tabular}{cccc}
\hline $\begin{array}{c}\text { Skor } \\
\text { total }\end{array}$ & Kategori & Frekuensi & $\begin{array}{c}\text { Presentase } \\
(\%)\end{array}$ \\
\hline$<36$ & Rendah & 11 & $36.67 \%$ \\
$\geq 36$ & Tinggi & 19 & $63.33 \%$ \\
& Total & 30 & 100 \\
\hline
\end{tabular}

Dari tabel di atas, terlihat bahwa sebagian odapus wanita dewasa awal di Syamsi Dhuha Foundation, yaitu sebanyak $63.33 \%$ atau 19 orang memiliki komponen kognitif subjective well-being yang tinggi, sedangkan $36.67 \%$ atau 11 orang memiliki komponen kognitif subjective well-being yang rendah. Artinya, sebagian besar odapus di Syamsi Dhuha Foundation memiliki evaluasi kognitif terhadap hidup yang tinggi.

\section{Sub-aspek Komponen Kognitif: Satisfaction with Life}

Berdasarkan perhitungan, pada subaspek satisfaction with life, didapatkan hasil sebagai berikut:

Tabel 12

Distribusi Frekuensi Satisfaction with Life

\begin{tabular}{cccc}
\hline $\begin{array}{c}\text { Skor } \\
\text { total }\end{array}$ & Kategori & Frekuensi & $\begin{array}{c}\text { Presentase } \\
(\%)\end{array}$ \\
\hline$<15$ & Rendah & 10 & $33.33 \%$ \\
$\geq 15$ & Tinggi & 20 & $66.67 \%$ \\
& Total & 30 & 100 \\
\hline
\end{tabular}

Dari tabel di atas, terlihat bahwa sebagian odapus wanita dewasa awal di
Syamsi Dhuha Foundation, yaitu sebanyak $66.67 \%$ atau 20 orang memiliki komponen satisfaction with life yang tinggi, sedangkan $33.33 \%$ atau 10 orang memiliki komponen kognitif satisfaction with life yang rendah. Artinya, sebagian besar odapus memiliki global life satisfaction yang tinggi.

\section{Sub-aspek Komponen Kognitif: Domain Satisfaction}

Berdasarkan perhitungan, pada subaspek domain satisfaction, didapatkan hasil sebagai berikut:

Tabel 13

Distribusi Frekuensi Domain Satis-faction

\begin{tabular}{cccc}
\hline $\begin{array}{c}\text { Skor } \\
\text { total }\end{array}$ & Kategori & Frekuensi & $\begin{array}{c}\text { Presentase } \\
(\%)\end{array}$ \\
\hline$<21$ & Rendah & 15 & $50 \%$ \\
$\geq 21$ & Tinggi & 15 & $50 \%$ \\
& Total & 30 & 100 \\
\hline
\end{tabular}

Dari tabel di atas, terlihat bahwa sebagian odapus wanita dewasa awal di Syamsi Dhuha Foundation, yaitu sebanyak $50 \%$ atau 15 orang memiliki komponen domain satisfaction yang tinggi, sedangkan $50 \%$ atau 15 orang memiliki komponen kognitif domain satisfaction yang rendah.

\section{Komponen Afektif}

Menurut Diener dkk. (2012), pleasant affect dikurangi dengan unpleasant affect, maka hasilnya akan bervariasi dari -24 (paling tidak bahagia) hingga 24 (paling bahagia). Oleh karena itu, berdasarkan perhitungan, pada komponen afektif subjective well-being, didapatkan hasil sebagai berikut:

Tabel 14

Distribusi Frekuensi Komponen Afektif

\begin{tabular}{cccc}
\hline $\begin{array}{c}\text { Skor } \\
\text { total }\end{array}$ & Kategori & Frekuensi & $\begin{array}{c}\text { Presentase } \\
(\%)\end{array}$ \\
\hline$<0$ & Rendah & 7 & $23.33 \%$ \\
$\geq 0$ & Tinggi & 23 & $76.67 \%$ \\
& Total & 30 & 100 \\
\hline
\end{tabular}

Dari tabel di atas, terlihat bahwa sebagian odapus wanita dewasa awal di 
Syamsi Dhuha Foundation, yaitu sebanyak $76.67 \%$ atau 23 orang memiliki komponen afektif subjective well-being yang tinggi, sedangkan $23.33 \%$ atau 7 orang memiliki komponen afektif subjective well-being yang rendah. Artinya, sebagian besar odapus menunjukkan lebih banyak pleasant affect ketimbang negative affect.

\section{Sub-aspek Komponen Afektif: Positive Affect}

Berdasarkan perhitungan, pada subaspek positive affect, didapatkan hasil sebagai berikut:

Tabel 15

Distribusi Frekuensi Positive Affect

\begin{tabular}{cccc}
\hline $\begin{array}{c}\text { Skor } \\
\text { total }\end{array}$ & Kategori & Frekuensi & $\begin{array}{c}\text { Presentase } \\
(\%)\end{array}$ \\
\hline$<18$ & Rendah & 10 & $33.33 \%$ \\
$\geq 18$ & Tinggi & 20 & $66.67 \%$ \\
& Total & 30 & 100 \\
\hline
\end{tabular}

Dari tabel di atas, terlihat bahwa sebagian odapus wanita dewasa awal di Syamsi Dhuha Foundation, yaitu sebanyak $66.67 \%$ atau 20 orang memiliki positive affect yang tinggi, sedangkan $33.33 \%$ atau 10 orang memiliki komponen kognitif positive affect yang rendah.

\section{Sub-aspek Komponen Afektif: Negative Affect}

Berdasarkan perhitungan, pada subaspek negative affect, didapatkan hasil sebagai berikut:

Tabel 17

Cross-tab Faset Gratitude dan Subjective Well-Being
Tabel 16

Distribusi Frekuensi Negative Affect

\begin{tabular}{cccc}
\hline $\begin{array}{c}\text { Skor } \\
\text { total }\end{array}$ & Kategori & Frekuensi & $\begin{array}{c}\text { Presentase } \\
(\%)\end{array}$ \\
\hline$<18$ & Rendah & 22 & $73.33 \%$ \\
$\geq 18$ & Tinggi & 8 & $26.67 \%$ \\
& Total & 30 & 100 \\
\hline
\end{tabular}

Dari tabel di atas, terlihat bahwa sebagian odapus wanita dewasa awal di Syamsi Dhuha Foundation, yaitu sebanyak $73.33 \%$ atau 22 orang memiliki negative affect yang rendah, sedangkan $26.67 \%$ atau 8 orang memiliki komponen kognitif negative affect yang tinggi.

\section{Cross-Tab Gratitude dan Subjective Well- Being}

Dari cross-tab faset disposisi gratitude dan subjective well-being, terlihat bahwa dari 21 orang yang memiliki sense of abundance yang tinggi, memiliki subjective well-being yang tinggi pula. Begitu pula, 4 orang odapus yang memiliki sense of abundance yang rendah, memiliki subjective well-being yang rendah pula. Namun ternyata, terdapat 5 orang odapus yang memiliki sense of abundance yang tinggi, namun subjective well-being yang rendah.

Selanjutnya, terdapat 25 orang yang memiliki faset appreciation of others yang tinggi, memiliki subjective well-being yang tinggi pula. Begitu pula, 4 orang odapus yang memiliki appreciation of others yang rendah, memiliki subjective well-being yang rendah pula. Namun, terdapat 5 orang

\begin{tabular}{cccccc}
\hline \multirow{2}{*}{ Faset Disposisi Gratitude } & & \multicolumn{3}{c}{ Derajat Subjective Well-Being } \\
\cline { 3 - 5 } & & & Tinggi & \multicolumn{2}{c}{ Rendah } \\
\cline { 3 - 5 } Sense of Abundance & Tinggi & 21 & $70 \%$ & 5 & $16,67 \%$ \\
Appreciation of Others & Rendah & 0 & $0 \%$ & 4 & $13,33 \%$ \\
& Tinggi & 25 & $83,33 \%$ & 5 & $16,67 \%$ \\
Appreciation of Simple Pleasures & Rendah & 0 & $0 \%$ & 4 & $13,33 \%$ \\
& Tinggi & 21 & $70 \%$ & 9 & $30 \%$ \\
Total & Rendah & 0 & $0 \%$ & 0 & $0 \%$ \\
& Tinggi & 21 & $70 \%$ & 6 & $20 \%$ \\
& Rendah & 0 & $0 \%$ & 3 & $10 \%$ \\
\hline
\end{tabular}


odapus yang memiliki appreciation of others yang tinggi, namun subjective wellbeing yang rendah.

Kemudian, terdapat 21 orang yang memiliki faset appreciation of simple pleasures yang tinggi, memiliki subjective well-being yang tinggi pula. Namun, terdapat 9 orang odapus yang memiliki appreciation of simple pleasures yang tinggi, namun subjective well-being yang rendah.

Jika dilihat dari total skor gratitude, terdapat 21 orang yang memiliki faset skor total gratitude yang tinggi, memiliki subjective well-being yang tinggi pula. Begitu pula, 3 orang odapus yang memiliki skor total gratitude yang rendah, memiliki subjective well-being yang rendah pula. Namun, terdapat 6 orang odapus yang memiliki skor total gratitude yang tinggi, namun subjective well-being yang rendah.

\section{Pembahasan}

\section{Hubungan Faktor Demografi dengan Gratitude dan Subjective Well-Being}

Dalam penelitian ini, dilakukan penghitungan rata-rata skor gratitude dan subjective well-being berdasarkan pada data demografi. Hasilnya terdapat pada tabel 18.

Dari tabel 18, pada faktor demografi kegiatan keagamaan, terdapat perbedaan skor rata-rata gratitude dan subjective well- being pada odapus di Syamsi Dhuha Foundation. Odapus yang melakukan kegiatan keagamaan memiliki tingkat gratitude trait dan subjective well-being yang tinggi, dibandingkan dengan mereka yang tidak mengikuti kegiatan keagamaan.

Selanjutnya, pada faktor demografi status pernikahan, tidak terdapat perbedaan skor rata-rata gratitude dan subjective wellbeing pada odapus di Syamsi Dhuha Foundation. Odapus yang belum menikah maupun yang sudah menikah sama-sama memiliki gratitude trait dan subjective well-being yang tinggi.

Terakhir, pada faktor demografi status kesehatan, tidak terdapat perbedaan skor rata-rata gratitude pada odapus di Syamsi Dhuha Foundation, dimana mereka yang memiliki status kesehatan remisi dan flare sama-sama memiliki skor rata-rata gratitude yang tinggi. Namun, terdapat perbedaan skor rata-rata subjective wellbeing. Odapus yang memiliki status kesehatan remisi memiliki subjective wellbeing yang tinggi, sedangkan odapus yang sedang flare memiliki subjective well-being yang rendah.

Gambaran Hubungan Gratitude dan Subjective Well-Being

Berdasarkan data yang diperoleh, dari subjek penelitian sejumlah 30 orang odapus

Tabel 18

Rata-rata Gratitude dan Subjective Well-Being Berdasarkan Data Demografi

\begin{tabular}{lccccc}
\hline \multirow{2}{*}{ Data Demografi } & & \multicolumn{4}{c}{ Skor Rata-rata } \\
\cline { 2 - 5 } & & Gratitude & Keterangan & $\begin{array}{c}\text { Subjective } \\
\text { Well-Being }\end{array}$ & Keterangan \\
\hline Kegiatan Keagamaan & Ya & 301,38 & Tinggi & 44 & Tinggi \\
& Tidak & 202 & Rendah & 13 & Rendah \\
Status Pernikahan & Menikah & 283,4 & Tinggi & 41 & Tinggi \\
& $\begin{array}{c}\text { Belum } \\
\text { Status Kesehatan }\end{array}$ & 289,12 & Tinggi & 40 & Tinggi \\
& Remisi & 291,91 & Tinggi & 48 & 28 \\
\end{tabular}


wanita dewasa awal di Syamsi Dhuha Foundation, ditemukan hubungan positif yang signifikan antara gratitude dan subjective well-being. Hasil ini, sesuai dengan teori yang dijabarkan sebelumnya bahwa gratitude dianggap sebagai faktor psikologis yang positif dan memiliki asosiasi yang erat dengan well-being (Mills, Wilson, Pung, Chinh, Greenberg, Lunde, Maisel, dan Raisinghani, 2015). Menurut Wood (2008; dalam Ruini dan Vescovelli, 2013) gratitude adalah prediktor yang penting terhadap kepuasan hidup dan afek positif.

Selanjutnya, dilakukan uji rankspearman antar tiap faset gratitude dengan subjective well-being. Hasilnya, terlihat bahwa ketiga faset gratitude memiliki hubungan positif yang signifikan dengan subjective well-being. Sense of abundance memiliki hubungan positif signiifikan yang sangat kuat dengan subjective well-being $(\mathrm{r}=0,904)$, paling tinggi dibandingkan dengan kedua faset lainnya. Artinya, seseorang yang menganggap hidupnya dilimpahkan oleh rahmat, menghargai pihak lain, dan menghargai hal-hal kecil di dalam hidup, akan memiliki kepuasan hidup yang tinggi, baik secara kognitif maupun afektif.

Melalui faset sense of abundance, seseorang akan mampu menganggap bahwa segala sesuatu yang dimilikinya adalah anugerah. McCullough dkk. (2002) berpendapat bahwa fokus terhadap blessings yang membuat seseorang bersyukur, secara langsung akan membuat seseorang tidak akan membuat perbandingan dengan orang lain yang memiliki lebih banyak darinya. Ia menemukan bahwa disposisi gratitude memiliki korelasi negatif dengan disposisi iri. Ketika individu memiliki gratitude terhadap apa yang ia miliki, ia tidak akan mau bersusah payah untuk membandingkan dengan apa yang dimiliki orang lain, misalnya kesehatan yang baik. Dengan tanpa membandingbandingkan dengan kesehatan orang lain inilah, seseorang akhirnya akan mampu merasa puas dan mencapai subjective wellbeing yang tinggi.

Melalui appreciation of others, seseorang akan selalu menyadari keterlibatan pihak lain di dalam hidupnya dan menyadari pentingnya mengekspresikan rasa syukur tersebut, sebab sumber dari kebaikan yang ada padanya bersifat eksternal, dimana "seseorang menyadari bahwa pihak lain bertanggung jawab atas kebaikan tersebut". Oleh karena itu, dirinya akan selalu mengekspresikan afek positif dan jarang mengekspresikan afek negatif sebagai bentuk ekspresi gratitude.

Melalui appreciation of simple pleasures, seseorang akan menghargai sekecil apapun kenikmatan yang ada, meski dalam keadaan sakit. Praktek dari gratitude mampu berfungsi sebagai copingmechanism yang efektif. Ketika seseorang cenderung menganggap bahwa hidup adalah anugerah, ia akan mampu melihat kebaikan yang ada, meski dalam situasi yang tidak menyenangkan, sehingga kepuasan hidupnya akan tinggi.

\section{Gambaran Gratitude}

Berdasarkan data yang diperoleh, didapatkan bahwa dari sejumlah 30 orang odapus wanita dewasa awal di Syamsi Dhuha Foundation, sebanyak 27 orang atau sebesar $90 \%$ memiliki disposisi gratitude yang tinggi, sementara itu, $10 \%$ sisanya memiliki gratitude yang rendah. Artinya, sebagian besar odapus di Syamsi Dhuha Foundation memiliki disposisi gratitude yang tinggi. Hal ini membuktikan bahwa variabel gratitude memang dapat dilihat sebagai sebuah disposisi, sebab disposisi akan tetap stabil dalam beragam circumstances. Dalam hal ini, para odapus tetap memiliki penghayatan dilimpahkan rahmat, penghargaan terhadap hal-hal kecil di dalam hidup, dan menghargai orang lain sebagai bagian dari nikmat yang ada dalam hidupnya, meskipun mereka ditimpa sakit seberat lupus. Seperti yang telah dijelaskan Rosenberg (1998; dalam Emmons dan McCullough, 2004), gratitude bersifat 
stabil, dimana disposisi ini tidak akan mudah berubah karena faktor-faktor eksternal.

Terdapat 3 faset dalam disposisi gratitude, yaitu sense of abundance, appreciation of others, dan appreciation of simple pleasures. Sebagian besar odapus memiliki ketiga faset yang tinggi. Dari ketiga faset tersebut, faset yang paling tinggi adalah appreciation of simple pleasures, artinya para odapus sangat menghayati hal-hal kecil di dalam hidupnya, seperti makanan yang nikmat, mata yang masih mampu melihat, sejuknya udara, masih diberi hidup, dan lain sebagainya.

\section{Gambaran Subjective Well-Being}

Berdasarkan data yang diperoleh, didapatkan bahwa dari sejumlah 30 orang odapus wanita dewasa awal di Syamsi Dhuha Foundation, sebanyak 21 orang atau sebesar $70 \%$ memiliki subjective well-being yang tinggi, sementara itu, 30\% atau sebanyak 9 orang sisanya memiliki subjective well-being yang rendah. Artinya, sebagian besar odapus wanita dewasa awal di Syamsi Dhuha Foundation memiliki tingkat kepuasan hidup, baik secara kognitif dan afektif yang tinggi.

Dari kedua komponen subjective wellbeing, komponen kognitif memiliki nilai yang lebih rendah dibandingkan dengan komponen afektif. Hal ini sama sekali tidak mengejutkan, di mana artinya, seorang odapus secara rasio menyadari bahwa domain satisfaction mereka terganggu, terutama dalam area kesehatan. Apalagi jika merujuk faktor demografi, sebagian besar odapus, yaitu 25 orang berstatus belum menikah, padahal $60 \%$ odapus wanita dewasa awal sudah berusia 29-40 tahun. Oleh karena itu, bukanlah hal yang mengherankan bahwa $50 \%$ odapus memiliki domain satisfaction yang rendah.

Meski begitu, secara afektif mereka tetap mampu menunjukkan afek positif yang tinggi dan afek negatif yang rendah. Padahal, menurut berbagai penelitian, orang dengan chronic illness atau disabilities (CID) seringkali memiliki kepuasan terhadap hidup yang rendah dibanding dengan mereka yang tidak memiliki CID (Dijkers, 1999: Krause, 1992, dalam Kim dkk., 2011). Artinya, meski diberi sakit kronis seperti lupus, dimana domain satisfaction mereka, terutama dalam aspek kesehatan terganggu, mereka tetap mampu menunjukkan kepuasan hidup secara keseluruhan yang tinggi. Penemuan di atas menunjukkan adanya top-down model, dimana perubahan dalam area kesehatan tidak berpengaruh ke dalam kepuasan hidup secara global. Hal ini sesuai penemuan Brief, Butcher, George, dan Link (1993), yang menyatakan bahwa domain satisfaction dipengaruhi oleh proses top-down. Secara spesifik, Brief menemukan bahwa trait kepribadian neuroticism (disposisi dengan kecenderungan memiliki perasaan dan pikiran yang negatif) memiliki pengaruh terhadap kepuasaan seseorang pada domain kesehatannya, yang juga kemudian memengaruhi life satisfaction secara global. Dalam hal ini, disposisi gratitude inilah yang membuat life satisfaction secara global menjadi tinggi.

Dengan kata lain, hasil ini sejalan dengan top-down model, yang menyatakan bahwa kepuasan hidup secara keseluruhanlah yang akan berpengaruh terhadap kepuasan hidup dalam aspek-aspek tertentu dalam diri seseorang, bukan sebaliknya. Hal ini sesuai dengan penemuan-penemuan sebelumnya, yang mana peneliti seringkali dikecewakan oleh begitu kecilnya efek dari variabel eksternal dan objektif terhadap subjective well-being seseorang. Cambell, Converse, dan Rodgers (1976, dalam Diener dkk., 1999), menemukan bahwa faktor demografik (misalnya usia, jenis kelamin, pendapatan, ras, pendidikan, dan status pernikahan) hanya memengaruhi sebesar kurang dari $20 \%$ dari variasi dalam subjective well-being. Andrews dan Withney (1976, dalam Diener dkk., 1999), hanya mendapatkan pengaruh sebesar $8 \%$ 
dari faktor-faktor eksternal (misalnya pendapatan, pendidikan, dan lain-lain) terhadap subjective well-being. Argyle (in press, dalam Diener dkk., 1999), mengatakan bahwa lingkungan luar hanya berpengaruh sebesar $15 \%$ terhadap variasi dalam subjective well-being.

\section{Gambaran Cross-Tab Gratitude dan Subjective Well-Being}

Dari hasil tabulasi silang antara faset gratitude dan subjective well-being, terlihat bahwa 21 orang yang memiliki faset sense of abundance yang tinggi, memiliki derajat subjective well-being yang tinggi pula, 25 orang yang memiliki faset appreciation of others yang tinggi, memiliki derajat subjective well-being yang tinggi pula, 21 orang yang memiliki faset appreciation of simple pleasures yang tinggi, memiliki derajat subjective well-being yang tinggi pula, dan 21 orang yang memiliki skor total gratitude yang tinggi, memiliki derajat subjective well-being yang tinggi pula. Artinya, sebagian besar responden menunjukkan hasil gratitude dan subjective well-being sesuai dengan teori dan hasil uji analisis.

Meski begitu, terdapat beberapa hasil responden yang tidak sesuai dengan hasil uji analisis. Menurut hasil uji analisis statistik, gratitude akan memiliki hubungan yang positif dengan subjective well-being, namun ternyata beberapa subjek tidak menunjukkan hal yang serupa.

Setelah dianalisis melalui data demografi, terlihat bahwa 5 orang yang memiliki sense of abundance yang tinggi namun subjective well-being yang rendah ternyata memiliki status kesehatan flare. Selanjutnya, 9 orang yang memiliki appreciation of simple pleasures yang tinggi, namun subjective well-being yang rendah, 5 orang memiliki status kesehatan flare dan tidak mengikuti kegiatan keagamaan, sementara 4 orang lainnya sedang memiliki status kesehatan flare. Lalu, 5 orang yang memiliki appreciation of others yang tinggi namun memiliki subjective well-being yang rendah, ternyata dilaporkan memiliki status kesehatan flare. Kemudian, 5 orang yang memiliki skor total gratitude yang tinggi namun melaporkan subjective well-being yang rendah, ternyata 1 orang diantaranya memiliki status kesehatan flare dan tidak mengikuti kegiatan keagamaan, sementara 5 orang lainnya memiliki status kesehatan flare.

\section{Gambaran Faktor Demografi}

Dalam penelitian ini, terdapat 3 faktor demografi yang diteliti, yaitu kegiatan keagamaan, status pernikahan, dan status kesehatan. Pada status keagamaan, terlihat sebagian besar odapus di Syamsi Dhuha Foundation mengikuti kegiatan keagamaan. Selanjutnya, pada faktor status pernikahan, sebagian besar odapus di Syamsi Dhuha Foundation usia dewasa awal ini belum menikah. Terakhir, pada status kesehatan, sebagian besar odapus di Syamsi Dhuha Foundation ini sedang mengalami remisi.

Pada faktor demografi kegiatan keagamaan, terdapat perbedaan skor ratarata gratitude dan subjective well-being pada odapus di Syamsi Dhuha Foundation. Odapus yang mengikuti kegiatan keagamaan memiliki tingkat gratitude trait dan subjective well-being yang tinggi, dibandingkan dengan mereka yang tidak mengikuti kegiatan keagamaan. Hal ini menguatkan penemuan sebelumnya dimana Eddington dan Shuman (2005), mengatakan bahwa berbagai studi yang besar dengan sampel nasional, menunjukkan bahwa subjective well-being berkorelasi secara signifikan terhadap kekuatan hubungan dengan Tuhan (Pollner, 1989), pengalaman ibadah (Poloma dan Pendleton, 1991), dan partisipasi keagamaan (Ellison, Gay, dan Glass, 1989).

Selanjutnya, pada faktor demografi status pernikahan, tidak terdapat perbedaan skor rata-rata gratitude dan subjective wellbeing pada odapus di Syamsi Dhuha Foundation. Odapus yang belum menikah maupun yang sudah menikah sama-sama 
memiliki gratitude trait dan subjective well-being yang tinggi. Hal ini dijelaskan oleh Cambell dkk. (1976, dalam Diener dkk., 1999), bahwa faktor demografik (misalnya usia, jenis kelamin, pendapatan, ras, pendidikan, dan status pernikahan) hanya memengaruhi sebesar kurang dari $20 \%$ dari variasi dalam subjective wellbeing. Andrews dan Withney (1976, dalam Diener dkk., 1999), hanya mendapatkan pengaruh sebesar $8 \%$ dari variabel di atas terhadap subjective well-being. Bahkan, Argyle (in press, dalam Diener dkk., 1999), mengatakan bahwa lingkungan luar hanya berpengaruh sebesar $15 \%$ terhadap variasi dalam subjective well-being. Artinya, jika seseorang memiliki disposisi gratitude yang tinggi, ia akan memiliki subjective well-being yang tinggi pula, tanpa memandang status pernikahan.

Selain itu, menurut hasil wawancara dengan para odapus wanita, seringkali mereka telat menikah, atau bahkan tidak menikah hingga usia tua. Hal ini disebabkan lupus merupakan penyakit yang menurun, sehingga jarang ada laki-laki yang mau untuk menerima hal tersebut. Hal tersebut membuat para odapus telah mempersiapkan diri untuk menghadapi kenyataan bahwa mereka tidak akan menikah, sehingga status pernikahan tidak lagi memengaruhi para odapus.

Pada faktor demografi status kesehatan, tidak terdapat perbedaan skor rata-rata gratitude pada odapus di Syamsi Dhuha Foundation, dimana mereka yang memiliki status kesehatan remisi dan flare samasama memiliki skor rata-rata gratitude yang tinggi. Namun, terdapat perbedaan skor rata-rata subjective well-being. Odapus yang memiliki status kesehatan remisi memiliki subjective well-being yang tinggi, sedangkan odapus yang sedang flare memiliki subjective well-being yang rendah. Hal ini memperkuat teori menurut Rosenberg (1998, dalam Emmons dan McCullough, 2004), bahwa gratitude affective trait merupakan treshold emosi yang bersifat stabil di dalam kepribadian seseorang. Oleh karena itu, meski odapus dalam keadaan flare sehingga harus lebih banyak beristirahat ketimbang dalam keadaan remisi, gratitude affective trait odapus tidak akan terpengaruh, sebab itu merupakan sesuatu yang bersifat ajeg di dalam kepribadiannya.

Sementara itu, subjective well-being bersifat kurang stabil, sebab pleasant dan unpleasant affect akan dipengaruhi oleh peristiwa yang baru yang terjadi di dalam hidup odapus. Hal ini menurut penelitian Stallings, Dunham, Gatz, Baker, dan Bengston (1997), bahwa pengalaman baik dalam kehidupan sehari-hari berkorelasi dengan munculnya pleasant affect, begitu pula sebaliknya, pengalaman yang buruk dalam kehidupan sehari-hari berkorelasi dengan unpleasant affect. Oleh karena itu, ketika odapus mengalami flare, adalah hal yang sangat wajar jika hal tersebut memengaruhi ekspresi afek odapus, yang kemudian akan memengaruhi subjective well-being odapus itu sendiri. Selain itu, hal ini juga mendukung bottom-up process (Diener dkk., 1999) yang berasumsi bahwa terdapat berbagai kebutuhan dasar dari manusia, dimana ketika kebutuhankebutuhan tersebut terpenuhi, maka seseorang akan menjadi memiliki subjective well-being yang tinggi. Maka, ketika odapus mengalami gangguan dalam kesehatannya, domain satisfaction kesehatannya akan terganggu, sehingga memengaruhi subjective well-being odapus secara keseluruhan.

\section{Simpulan dan Saran}

Berdasarkan hasil penelitian dan pembahasan, maka dapat ditarik kesimpulan bahwa terdapat hubungan positif signifikan antara gratitude dan subjective well-being pada wanita odapus dewasa awal di Syamsi Dhuha Foundation ( $\mathrm{r}=$ 0,875). Hal ini berarti odapus yang memiliki gratitude tinggi akan memiliki subjective well-being yang tinggi pula.

Terdapat hubungan positif yang signifikan pada ketiga faset gratitude, yaitu 
sense of abundance, appreciation of others, dan appreciation of simple pleasures dengan subjective well-being. Faset sense of abundance dengan subjective well-being memiliki korelasi sebesar rs $=0,899$, faset appreciation of simple pleasures dengan subjective well-being memiliki korelasi sebesar rs $=0,752$, dan faset appreciation of others dengan subjective well-being memiliki korelasi sebesar rs $=0,766$.

Odapus di Syamsi Dhuha Foundation sebagian besar memiliki disposisi gratitude yang tinggi yaitu sebanyak 27 orang (90\%), sementara 3 orang lainnya $(10 \%)$ memiliki disposisi gratitude yang rendah. Faset yang paling tinggi adalah appreciation of simple pleasures, yaitu sebesar $100 \%$ odapus. Artinya odapus di Syamsi Dhuha Foundation sangat menghayati kenikmatan-kenikmatan kecil di dalam hidup.

Odapus di Syamsi Dhuha Foundation sebagian besar memiliki tingkat subjective well-being yang tinggi yaitu sebanyak 21 orang $(70 \%)$, sementara 9 orang $(30 \%)$ memiliki subjective well-being yang rendah. Komponen yang paling tinggi adalah komponen afektif dibandingkan dengan komponen kognitif. Artinya, secara rasio, para odapus menyadari bahwa domain satisfactions, terutama area kesehatan mengalami gangguan. Namun, kenyataan tersebut tidak menghentikan mereka menunjukkan afek positif yang tinggi dan afek negatif yang rendah.

Terdapat perbedaan tingkat gratitude dan subjective well-being berdasarkan kegiatan keagamaan. Odapus yang mengikuti kegiatan keagamaan memiliki tingkat gratitude dan subjective well-being yang tinggi, sebaliknya, yang tidak mengikuti kegiatan keagamaan, memiliki tingkat gratitude dan subjective well-being yang rendah.

Terdapat perbedaan tingkat subjective well-being berdasarkan status kesehatan. Odapus yang memiliki status kesehatan remisi memiliki tingkat gratitude dan subjective well-being yang tinggi, sebaliknya, yang memiliki status kesehatan flare, memiliki tingkat gratitude dan subjective well-being yang rendah.

Terakhir, dapat ditarik kesimpulan bahwa tidak terdapat perbedaan tingkat gratitude maupun subjective well-being odapus di Syamsi Dhuha Foundation berdasarkan status pernikahan. Hal ini dikarenakan, sebagian besar odapus di Syamsi Dhuha Foundation memilih untuk tidak menikah, sebab memahami bahwa Lupus merupakan penyakit menurun. Hal ini membuat odapus sudah mempersiapkan diri, sehingga membuat mereka tidak terpengaruh dengan keadaan tersebut.

Dari paparan di atas, terdapat beberapa saran yang dapat diaplikasikan untuk berbagai pihak, yaitu sebagai pertama, bagi Syamsi Dhuha Foundation, topik gratitude (syukur) dapat digunakan sebagai materi dalam tafakur setiap hari Sabtu. Hal ini dimaksudkan agar para odapus dapat semakin meningkatkan subjective wellbeing masing-masing. Selain ini, hal ini juga berguna untuk tercapainya cita-cita Syamsi Dhuha Foundation, yaitu memberikan kesempatan bagi odapus, untuk mensyukuri segala karunia yang telah Tuhan berikan. Syamsi Dhuha Foundation sebaiknya mengadakan kegiatan keagamaan lainnya, misalnya diskusi keagamaan setiap minggu, sehingga dapat meningkatkan gratitude dan subjective well-being para odapus.

Bagi pihak odapus sendiri yang masih memiliki tingkat gratitude yang rendah, agar lebih banyak sharing dengan para odapus yang sudah memiliki tingkat gratitude yang tinggi di sela-sela beraktivitas di Syamsi Dhuha Foundation, agar dapat meningkatkan subjective wellbeing pribadi.

Untuk peneliti selanjutnya, disarankan untuk memperluas penelitian mengenai gratitude dan subjective well-being pada odapus sehingga semakin ekstensif. Selain itu, disarankan untuk menganalisis lebih mendalam terkait faktor kegiatan keagamaan dan kesehatan yang dapat 
memengaruhi antara gratitude dan subjective well-being odapus.

\section{Daftar Pustaka}

Brief, A.P., Butcher, A.H., George, J.M., \& Link, K.E. (1993). Integrating Bottom-up and Top-down Theories of Subjective Well-Being: The Case of Health, Journal of Personality and Social Psychology, 64(4), 646653.

Diener, E. (1987). Subjective Well-Being, Psychological Bulletin, 95(3), 542575.

Diener, E., Suh, E., Lucas, R. \& Smith, H. (1999). Subjective Well-Being: Three Decades of Progress, 125(2), 276-302

Diener, E., Oishi, S., \& Lucas, R. (2012) Subjective Well-Being: The Science of Happiness and Life Satisfcation, The Oxford Handbook of Positive Psychology (2 ed.), DOI: 10.1093/oxfordhb/9780195187243. 013.0017

Dijkers, MPJM. (1999). Correlates of Life Satisfaction among Persons with Spinal Cord Injury, Arch Phys Med Rehabil 80:867-876. http://www.ncbi.nlm.nih.gov/pubme $\mathrm{d} / 10453761$

Eddington, N. \& Shuman, R. (2005). Subjective Well Being (Happiness), Continuing Psychology Education: 6 Continuing Education Hours, Diunduh pada 28 September 2015 dari

http://www.texcpe.com/cpe/PDF/ca happiness.pdf.

Ellison, C.G., Gay, D.A., \& Glass, T.A. (1989). Does Religious Commitment Contribute to Individual Life Satisfaction?, Social Forces, 68, 100-123.

Emmons R.A. \& McCullough, M.E. (2004). The Psychology of
Gratitude, New York: Oxford University Press, Inc.

Emzir. (2009). Metodologi Penelitian Pendidikan Kualitatif dan Kuantitatif, Jakarta: PT Raja Grafindo Pergoda.

Fraenkel, J.R. \& Wellen, N.E. (2008). How to Design and Evaluate Research in Education, New York: McGrawHill.

Glover, R.J. (2000). Developmental Tasks of Adulthood: Implications for Counseling Community College Students, Community College Journal of Research \& Practice, 24, $1-5$

Hitzig, S.L., Romero, Escobar E.M., Noreau, L., \& Craven, B.C. (2012). Validation of the Reintegration to Normal Living Index for Community-dwelling Persons with Chronic Spinal Cord Injury, Arch Phys Med Rehabil, 93, 10814.http://www.ncbi.nlm.nih.gov/pub $\mathrm{med} / 22200389$

Kim, J.H., Berven, N.L., Chan, F., Gonzalez, R., Miller, D.J., \& Keck, P.S. (2011). Virtues in Relation to Subjective Well-Being for People With Chronic Illness and Disability, Journal of Asia Pacific Counseling, 1(1), 61-76 doi:10.1111/j.17580854.2010.01045.x

Krause, J.S., Saunders, L.L., Reed, K.S., Coker, J., Zhai, Y., \& Johnson, E. (2009). Comparison of the Patient Health Questionnaire and the Older Adult Health and Mood Questionnaire for Self-reported Depressive Symptoms after Spinal Cord Injury, Rehabilitation Psychology, 54(4), 440-448. http://www.ncbi.nlm.nih.gov/pubme d/19929126. doi: 10.3233/NRE2009-0453.

Kulczycka, L. Sysa-Jędrzejowska, A., Robak, E. (2011). The Influence of Clinical Manifestations and Treatment on Satisfaction with Life 
together with Positive and Negative Emotions in Systemic Lupus Erythematosus Patients, 19(1), 612.

McCullough, M.E., Emmons R.A., \& Tsang, J. (2002). The Grateful Disposition: A Conceptual and Empirical Topography, Journal of Personality and Social Psychology, 82(1), DOI: 10.1037//00223514.82.1.112

Mills, P.J., Redwine, L., Wilson, K., Pung, M.A., Chinh, K., Greenberg, B.H., Lunde, O., Maisel, A., \& Raisinghani, A. (2015). The Role of Gratitude in Spiritual Well-Being in Asymptomatic Heart Failure Patients, Spirituality in Clinical Practice, 2(1), 5-17 http://dx.doi.org/10.1037/scp000005 $\underline{0}$

Paramita, R. \& Margaretha (2013). Pengaruh Penerimaan Diri terhadap Penyesuaian Diri Penderita Lupus, Jurnal Psikologi Undip, 12(1).

Permata, S.R. (2014). Hubungan antara Dukungan Sosial dengan SelfEsteem pada Odapus Systemic Lupus Erythomatus di RSUP dr. Hasan Sadikin Bandung, Skripsi, Bandung: Universitas Islam Bandung

Perhimpunan Reumatologi Indonesia. (2011). Diagnosis dan Pengelolaan Lupus Eritematosus Sistemik. Perhimpunan Reumatologi Indonesia. ISBN 978-979-3730-165

Pollner, M. (1989). Divine Relations, Social Relations, and Well-Being, Journal of Health and Social Behavior, 30, 92-104.

Poloma, M.M. \& Pendleton, B.F. (1991). The Effects of Prayer and Prayer Experiences on Measures of General Well-Being, Journal of Psychology and Theology, 29, 7183.
Post, M.W., van Leeuwen, C.M., van Koppenhagen, C.F., \& de Groot, S. (2012). Validity of the Life Satisfaction Questions, the Life Satisfaction Questionnaire, and the Satisfaction with Life Scale in Persons with Spinal Cord Injury, PubMed,

DOI: 10.1016/j.apmr.2012.03.025

Prasetyo, A.R. \& Kustanti, E.R. (2014). Bertahan dengan Lupus: Gambaran Resiliensi Pada Odapus, 13(2), 139148.

Richardson, E.J. \& Richards, J.S. (2008). Factor Structure of the PHQ-9 Screen for Depression across Time since Injury among Persons with Spinal Cord Injury, Rehabilitation Psychology, 53(2), 243-249. http://psycnet.apa.org/journals/rep/5 $\underline{3 / 2 / 243 /}$

Ruini, C., Vescovelli, F. (2013). The Role of Gratitude in Breast Cancer: Its Relationships with Post-Traumatic Growth, Psychological Well-Being and Distress, Journal Happiness Study, $\quad 14, \quad 263-274 \quad$ DOI 10.1007/s10902-012-9330-x

Scherer, M.J. \& Cushman, L.A. (2001). Measuring Subjective Quality of Life for Spinal Cord Injury: a Validation Study of the Assistive Technology Devise Predisposition Assessment, Disability and Rehabilitation, 23(9), 387-393. http://www.ncbi.nlm.nih.gov/pubme d/11394589

Stallings, M.C., Dunham, C.C., Gatz, M., Baker, L.A., \& Bengtson, V.L. (1997). Relationships among Life Events and Psychological WellBeing: More Evidence for a TwoFactor Theory of Well-Being, Journal of Applied Gerontology, 16, 104-119. 
Suryabrata, Sumadi. (1994). Metodologi Penelitian, Jakarta: Raja Grafindo Persada

Watkins, P.C., Woodward, Katharane, Stone, Tamara, Kolts, Russell, L. (2002). Gratitude and Happiness: Development of a Measure of Gratitude, and Relationship with Subjective Well-Being, Social Behavior \& Personality: An International Journal, 31, 431-452. http://dx.doi.org/10.13072/midss. 10 0
Watkins. (2013). Gratitude and the Good Life: Toward a Psychology of Appreciation, New York: Springer Science+Business Media Dordrecht DOI 10.1007/978-94-007-7253-3 1

Yennya \& Herwana, E. (2006). Prevalensi Penyakit Kronis dan Kualitas Hidup pada Lanjut Usia di Jakarta Selatan, Universa Medicina, 25(4).

Zar, Jerrold H. (1984). Biometry, New Jersey: Prentice-Hall. 
Psympathic, Jurnal Ilmiah Psikologi Juni 2017, Vol. 4, No.1, Hal: 91 - 114 